\title{
Animal Models of Head Trauma
}

\author{
Ibolja Cernak
}

Department of Neuroscience Georgetown University Medical Center, Washington, D.C. 20057

\begin{abstract}
Summary: Animal models of traumatic brain injury (TBI) are used to elucidate primary and secondary sequelae underlying human head injury in an effort to identify potential neuroprotective therapies for developing and adult brains. The choice of experimental model depends upon both the research goal and underlying objectives. The intrinsic ability to study injuryinduced changes in behavior, physiology, metabolism, the blood/tissue interface, the blood brain barrier, and/or inflammatory- and immune-mediated responses, makes in vivo TBI models essential for neurotrauma research. Whereas human TBI is a highly complex multifactorial disorder, animal trauma models tend to replicate only single factors involved in the
\end{abstract}

pathobiology of head injury using genetically well-defined inbred animals of a single sex. Although such an experimental approach is helpful to delineate key injury mechanisms, the simplicity and hence inability of animal models to reflect the complexity of clinical head injury may underlie the discrepancy between preclinical and clinical trials of neuroprotective therapeutics. Thus, a search continues for new animal models, which would more closely mimic the highly heterogeneous nature of human TBI, and address key factors in treatment optimization. Key Words: Traumatic brain injury, models, in vivo, neuronal cell death, outcome.

\section{INTRODUCTION}

Traumatic brain injury is a complex process and consists of four overlapping phases, which include primary injury, evolution of the primary injury, secondary or additional injury, and regeneration. ${ }^{1}$ Primary injury to the brain can be induced by numerous mechanisms, which include the following major categories: 1) direct contusion of the brain from the skull; 2) brain contusion caused by a movement against rough interior surfaces of the skull, and/or indirect (contracoup) contusion of the brain opposite the side of the impact; 3) shearing and stretching of the brain tissue caused by motion of the brain structures relative to the skull and each other; 4) vascular response to the impact including subdural hematoma produced by rupture of bridging blood vessels located between brain and dura mater; decreased blood flow due to increased intracranial pressure or infarction; ${ }^{2}$ and brain edema caused by increased permeability of cerebral blood vessels. Diffuse axonal injury has been recognized as one of the main consequences of blunt head trauma; it is characterized by morphological and

Address correspondence and reprint requests to Ibolja Cernak, M.D., Ph.D., Department of Neuroscience, Georgetown University Medical Center, Research Building, Room EP04, Washington, D.C. 20057.

E-mail: ifc@georgetown.edu. functional damages of axons throughout the brain and brainstem and leads to diffuse degeneration of cerebral white matter. ${ }^{3}$ Secondary injury mechanisms include complex biochemical and physiological processes, which are initiated by the primary insult and manifest over a period of hours to days. ${ }^{4}$ It has been established that such secondary injury may significantly contribute to posttraumatic neurological disability. ${ }^{5}$

The purpose of experimental models of traumatic brain injury (TBI) is to replicate certain pathological components or phases of clinical trauma in experimental animals aiming to address pathology and/or treatment. ${ }^{2}$ The design and choice of a specific model should emulate the goal of the research. For example, characterization of the biomechanics of injury may necessitate a different model than evaluation of molecular mechanisms of tissue loss, or testing the efficacy of novel therapeutic treatments. ${ }^{2}$ Whereas earlier models addressed biomechanical aspects of brain injury, ${ }^{6,7}$ recent models are more targeted toward improving the understanding of complex molecular detrimental cascades initiated by trauma. ${ }^{8,9}$ Regardless of the goals, it is vital that the chosen experimental model satisfies the following criteria: 1) the mechanical force used to induce injury is controlled, reproducible, and quantifiable; 2) the inflicted injury is reproducible, quantifiable, and mimics components of human conditions; 3 ) the injury outcome, mea- 
In Vivo Models of Traumatic Brain Injury

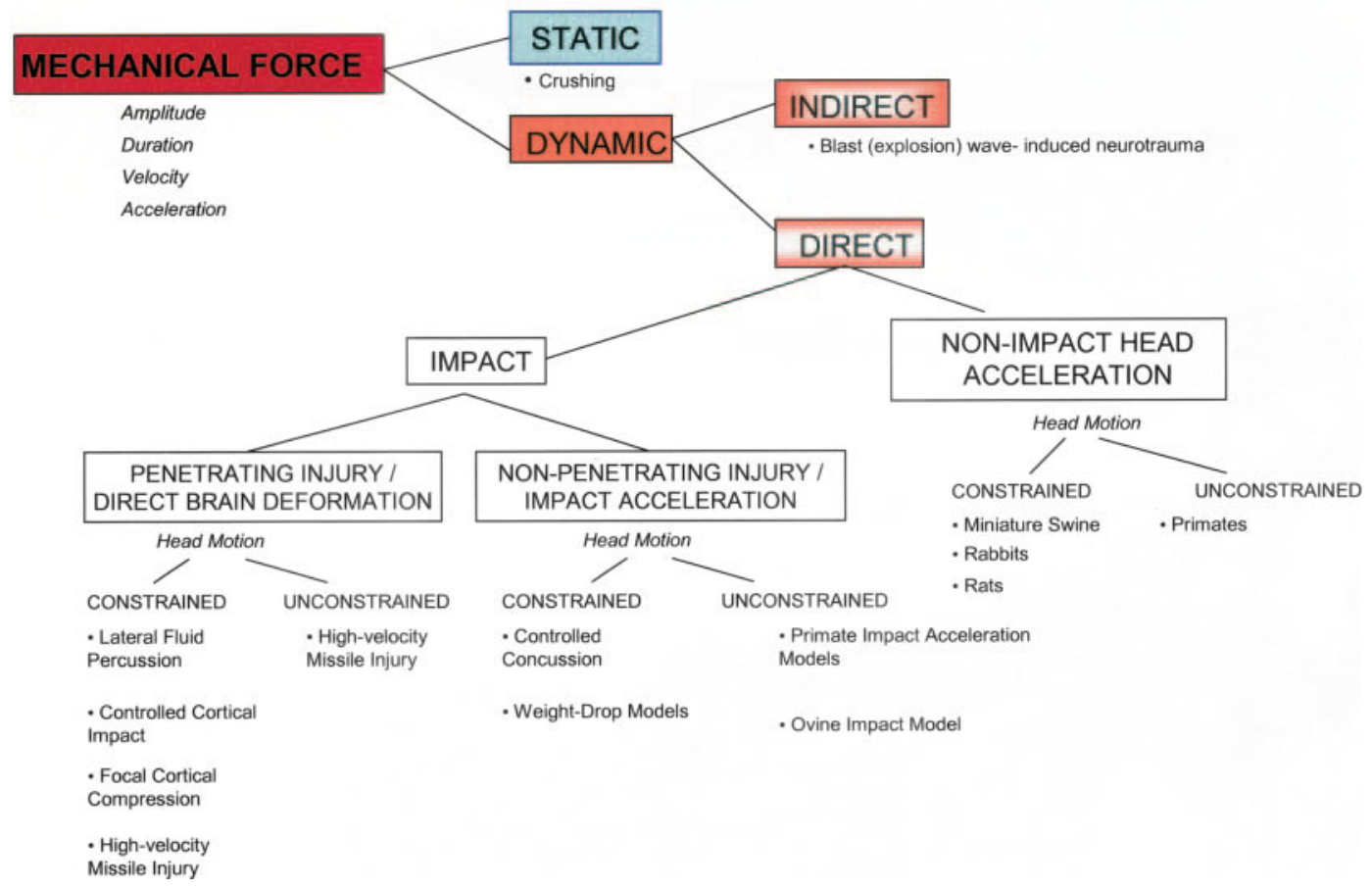

FIG. 1. Schematic representation of in vivo experimental models of traumatic brain injury.

sured by morphological, physiological, biochemical, or behavioral parameters, is related to the mechanical force causing the injury; and 4) the intensity of the mechanical force used to inflict injury should predict the outcome severity.

Despite differing opinions regarding the preferred species used for modeling human TBI, ${ }^{10}$ many investigators have accepted rodent models as the most suitable choice for neurotrauma research. Indeed, the relatively small size and cost of rodents permits repetitive measurements of morphological, biochemical, cellular, and behavioral parameters that require relatively large numbers of animals. Because of ethical, technical, and/or financial limitations, such studies are less achievable in phylogenetically higher species than rodents. However, differences between rodent and human systemic physiological and behavioral responses to neurotrauma have raised concerns about the use of rodents. ${ }^{11}$ Moreover, it has been suggested that the lissencephalic rodent cortex is inappropriate for modeling the more complex changes in the anatomy of human cortex. Nevertheless, rodents remain the most commonly used animals for modeling human TBI.

The available literature ${ }^{2,11,12}$ presents numerous and somewhat differing classifications of experimental TBI models. The pioneering work by Denny-Brown and Russell ${ }^{6}$ differentiates two major categories of experimental brain injury: acceleration concussion and percussion concussion. Classifications of experimental TBI models defined afterward have often been based upon this work. ${ }^{11,12}$ To understand major biomechanical concepts used to design some of the most popular animal models of TBI, and weigh the pros and cons of these models, in this review we offer a different classification (FIG. 1), which incorporates the biomechanical paradigms of TBI initially proposed by Ommaya and colleagues. ${ }^{13,14}$

As shown in Figure 1, mechanical force inflicts either dynamic or static brain trauma, depending on its amplitude, duration, velocity and acceleration. The mechanical force in static models possesses defined amplitude and duration, whereas the velocity and acceleration are irrelevant. Inherently, the static models usually focus on morphological and functional processes involved in injury. ${ }^{15,16}$ Crushing a cranial nerve with forceps for a defined period of time would be an example for a static CNS injury model. ${ }^{15}$ On the other hand, mechanical force, with well-characterized amplitude, duration, velocity, and/or acceleration, inflicts dynamic brain injury. Dynamic brain trauma can be further subdivided into direct and indirect injury. In the case of indirect dynamic brain injury, the mechanical force is generally directed at the whole body with the kinetic energy of the oscillating pressure waves that traverse the body imparting their effects on brain tissue.

\section{DYNAMIC DIRECT BRAIN INJURY}

Based on the existence of a direct impact and/or acceleration, direct dynamic brain injuries can be classified 
as impact or nonimpact/acceleration head injury models. Both impact and nonimpact injuries can be further divided depending on the head motion at the moment of injury; namely, whether the head motion is constrained to a single plane, or the head is unconstrained and allowed to move freely. ${ }^{2}$

\section{Impact brain injury: penetrating head injury/direct brain deformation}

Penetrating head injury and other direct brain deformation models are caused by the impact energy, which is delivered to the brain parenchyma through a skull perforated by a missile or a craniotomy.

Fluid percussion injury (FPI) models. The FPI is one of the most frequently used direct brain deformation models. Indeed, it has been found suitable for the study of injury pathology, ${ }^{17,18}$ physiology, ${ }^{19,20}$ and pharmacology $^{21,22}$ in a wide range of species, including rats, ${ }^{23,24}$ mice, ${ }^{25,26}$ cats, ${ }^{27,28}$ pigs, ${ }^{29,30}$ rabbits, ${ }^{31}$ and dogs and sheep. ${ }^{32}$ In this model, the insult is inflicted by application of a fluid pressure pulse to the intact dura through a craniotomy, which is made either centrally (vertex) ${ }^{33,34}$ around the midline between bregma and lambda, or laterally usually over the left parietal bone between bregma and lambda, $4.0 \mathrm{~mm}$ lateral to the sagittal suture ${ }^{35-37}$; the craniotomy may be in combination with or without a contralateral skull opening. Briefly, the anesthetized animals are placed in a stereotaxic frame and their scalp and temporal muscles reflected. A small craniotomy is made to allow insertion of a plastic cap that is cemented into place. The FPI device consists of a Plexiglas cylindrical reservoir filled with sterile isotonic saline. One end of the reservoir includes a transducer, which is mounted and connected to a tube that attaches through a plastic fitting to the cap cemented on the animals' skull at the time of surgery. The strike of a pendulum at the opposite end of the cylindrical reservoir generates a pressure pulse that is delivered to the intact dura and causes deformation of underlying brain. The severity of injury depends on the pressure pulse. ${ }^{35,38}$ Recent studies ${ }^{39,40}$ have emphasized the importance of craniotomy position in lateral fluid percussion injury. Indeed, it has been shown that when the craniotomy was positioned less than $3.5 \mathrm{~mm}$ away from the sagittal suture, damages of both ipsilateral and contralateral cortices could be seen by magnetic resonance imaging (MRI) and/or histological analysis. Additionally, when the craniotomy position is located farther than $3.5 \mathrm{~mm}$ from the sagittal suture, no contralateral injury was found. ${ }^{39}$ It has been concluded that careful attention to craniotomy position should be paid aiming to increase reliability and reproducibility of this model. $^{41}$

Generally, central and lateral FPIs have comparable pathobiology, although distinct differences have also been reported between the two models. ${ }^{11,42}$ The lateral
FPI model inflicts primarily unilateral cortical damage, rarely involving the contralateral cortices and brainstem, whereas central FPI causes bilateral cortical alterations associated with direct axial movement of the lower brainstem. ${ }^{11,12}$ The immediate physiological response to both types of FPIs comprises of changes in blood pressure (mainly a transient hypertension), ${ }^{23,35}$ brief respiratory arrest, ${ }^{43,44}$ elevated craniocerebral pressure, ${ }^{29}$ decreased cerebral perfusion pressure, ${ }^{29}$ reduced cerebral blood flow, ${ }^{29}$ and increased cerebral vascular resistance. ${ }^{29}$ Moreover, alterations in cerebral blood flow $^{29,45,46}$ and increased permeability of the blood-brain barrier have been shown in both FPI models. ${ }^{34,35,47}$ The most frequently reported histopathological findings are: petechial hemorrhage in the brain parenchyma, ranging from minor to fatal confluent hemorrhage, axonal damage, subarachnoid hemorrhage, tissue tears followed by focal necrosis and cell loss, and characteristic vascular damage at the gray/white interface defined as "gliding contusion." $33,35,43,48-52$ Both types of neuronal cell death, necrosis and apoptosis, have been found in these FPI models. ${ }^{52-54}$ Moreover, central and lateral FPI models have been linked to altered ionic homeostasis, including elevated intracellular calcium ${ }^{55,56}$ and tissue sodium, ${ }^{57-59}$ impaired potassium equilibrium, ${ }^{58,60,61}$ and decreased intracellular free magnesium. ${ }^{22,62-64}$ Hyperand hypometabolism have been also shown in both experimental models. ${ }^{65,66}$ Additionally, EEG depression, ${ }^{23,35,67,68}$ motor, ${ }^{22,33,69}$ behavioral and cognitive deficits $^{40,70-72}$ have been reported after both types of fluid percussion injuries. It is noteworthy that the central FPI generates only limited injury dose response because of death due to autonomic dysfunction at hypothalamic levels. Hence, the resultant changes in bioenergetics and cerebral blood flow are limited as compared to the lateral FPI method. Conceptually, this may explain the controversial findings in the literature.

The lateral fluid percussion model provides an injury that replicates clinical contusion without skull fracture, and which shows a direct relationship between the majority of pathological alterations and injury severity. Thus, it is widely used in neurotrauma research for both mechanistic studies and for drug screening. However, the utilization of FPI models is limited by increased severity and/or increased morbidity mainly due to disproportional involvement of the brainstem and development of neurogenic pulmonary edema. These and other limitations, such as restricted biomechanical control and inability to reflect the entire complexity of human TBI, prompted the search for alternative TBI models.

Controlled cortical impact models. Controlled cortical impact (CCI) models are sometimes described as rigid percussion models. ${ }^{11,12}$ This type of head trauma has been used in the ferret, ${ }^{73}$ rat, $^{74,75}$ and mouse. ${ }^{76}$ This model allows for better control over mechanical factors, 
such as velocity of impact and depth of resulting deformation, thus it offers potential advantages over the fluid percussion model, especially in biomechanical studies of TBI. The controlled impact is delivered to the intact dura by a compressed air-driven metallic piston causing deformation of the underlying cortex. ${ }^{74,77}$ Briefly, the device used in rodent CCI models consists of a pneumatic cylinder usually with a $4-$ to $5-\mathrm{cm}$ stroke, which is mounted on a cross bar so that the position of the impactor can be adjusted. The impact velocity used in the majority of studies is between 0.5 and $10 \mathrm{~m} / \mathrm{s}$ depending on air pressure that drives the impactor. The depth of cortical deformation is controlled by vertical adjustment of the crossbar holding the cylinder and can be varied from between 1 and $3 \mathrm{~mm}$, whereas the duration of the impact (dwell time) can be adjusted between 25 and $250 \mathrm{~ms}$. It has been shown that cerebral hemodynamic responses such as elevated intracranial pressure, decreased blood and cerebral perfusion pressures, ${ }^{77}$ histological ${ }^{75,78}$ and cellular alterations, ${ }^{8,79,80}$ as well as functional deficits ${ }^{76,81}$ are related to both the depth of deformation and the velocity of the impact. Impacts inflicted at a velocity higher than $4.3 \mathrm{~m} / \mathrm{s}(4.3-8.0 \mathrm{~m} / \mathrm{s})$ and with a depth of cortical deformation from $1.0 \mathrm{~mm}$ initiate widespread acute and chronic neuronal injury. ${ }^{78,82-84}$ Pathoanatomical alterations, including diffuse axonal injury, have been found in white matter of the subcortical region and cerebellar folia, internal capsule, thalamic nuclei, midbrain, pons, and medulla. ${ }^{2,12}$ This model also induces coma of varying length. ${ }^{12}$ In general, controlled cortical impact injury produces a more focused injury compared with lateral fluid percussion, which may have implications with respect to the behavioral suppression and/or functional alterations resembling coma. ${ }^{85}$ Taken together, the pathobiology of controlled cortical impact injury reproduces changes reported in clinical head injuries such as brain edema, ${ }^{86}$ elevated intracerebral pressure, reduced cortical perfusion, ${ }^{77}$ decreased cerebral blood flow, ${ }^{87}$ neuroendocrine and metabolic changes, ${ }^{88}$ and coma. ${ }^{12}$ Hence this model, which replicates clinical brain injury with skull deformation and related cortical compression, is extensively used to analyze complex molecular $^{89-92}$ and genetic ${ }^{93,94}$ mechanisms underlying neuronal cell death and resulting neurological deficits following TBI. It is also a valuable tool for developing novel therapeutic approaches for brain injuries. ${ }^{95-102}$

Other direct brain-deformation models. Additional experimental models have been designed to generate dynamic cortical deformation, including: a vacuum pulse of clinically relevant duration $(<100 \mathrm{~ms})^{103,104}$; microinjection of a fluid containing zymosan (an inert particulate macrophage activator), lipopolysaccharide, and latex microspheres into the brain parenchyma to induce progressive cavitation ${ }^{105}$; a mechanical suction force applied through the intact dura ${ }^{106}$; and focal cortical cry- olesion, ${ }^{107}$ among others. ${ }^{108,109}$ Although these models use different forms of a mechanical force to produce cortical injury, each of them basically induces localized morphological alterations with corresponding metabolic effects. Because of the absence of extensive diffuse injuries, these models do not cause significant long-term deficits that would be of importance to clinical TBI. Nevertheless, these models are helpful in studies evaluating pathoanatomy of localized contusions and/or for quality control of treatments aimed to reduce the size of focal lesions. ${ }^{2}$

Impact brain injury: high-velocity missile injury. Experimental models of traumatic craniocerebral missile injury have been designed to study cerebral pathophysiology of a missile wound to the brain. ${ }^{110-114}$ One of the frequently used models was developed by Carey et al. ${ }^{114-116}$ using anesthetized mongrel cats. Briefly, the animals are placed in a stereotaxic frame, wherein the sloping outer wall of the right frontal sinus is removed thus allowing the missile to penetrate the intact and vertically disposed posterior sinus wall. A 2-mm, 31-mg steel sphere fired from a distance of $80 \mathrm{~cm}$ at either 220 or $280 \mathrm{~m} / \mathrm{s}$ penetrates the right frontal bone and traverses the right cerebral hemisphere from anterior to posterior. The energy of a missile delivered to the brain varies between 0.9 and $1.4 \mathrm{~J}$. This model produces vasogenic edema around the missile wound track in the injured hemisphere, ${ }^{114,115}$ elevated intracranial pressure, decreased cerebral perfusion pressure, increased blood glucose, transient increase in hematocrit, and respiratory arrest. These changes are most likely energy dependent. ${ }^{116}$

Finnie's model ${ }^{112}$ utilizes a 0.22 -caliber firearm to inflict head wounds in a physically restrained sheep from a range of $3 \mathrm{~m}$ with the animal's head held in an upright position. The bullet is fired at the temporal region of the skull, and causes a right-to-left transverse wound to the brain through the temporal lobes. Morphological alterations include crushing and laceration of tissue and related hemorrhagic cavity, widespread stretch injuries to blood vessels, nerve fibers and neurons, as well as distortion and displacement of the brain.

These models are valuable in studies characterizing histopathological features of a missile wound. However, they offer less opportunity to evaluate complex molecular responses and functional outcomes after brain injury due to the size of the animal.

\section{Impact brain injury: nonpenetrating/closed head injury}

Controlled concussion models. There are various closed head impact models, which have been designed to replicate the biomechanics and pathobiology of human concussive and diffuse brain injury. ${ }^{17-119}$ This type of brain injury is difficult to reproduce with fluid percussion, cortical impact, or focal brain contusion models 
because injuries generated using these techniques are associated with focal axonal damage rather then causing diffuse axonal injury. Indeed, skull fracture, subdural-, subarachnoid-, and intracerebral hemorrhages, as well as convulsions, frequently have been found to accompany injuries produced by these methods. Moreover, many of these animal models failed to induce a graded, reproducible range of injury outcomes through alteration of the mechanical force. Histopathological alterations these techniques induced were restricted to the lower brainstem, and were not comparable with morphological changes seen in the human brain following injury. ${ }^{2},{ }^{120}$

Tornheim and colleagues ${ }^{121,122}$ developed a method with cats subjected either to a blow that was delivered to the coronal suture by a Remington humane stunner ${ }^{121}$ or to an oblique lateral impact. ${ }^{123}$ The blunt craniocerebral trauma generated skull fractures, epidural hematoma, subdural and subarachnoid hemorrhages, and brain contusions. ${ }^{123}$ This method also initiated metabolic changes, ${ }^{124}$ edema, ${ }^{121}$ and decreased regional cerebral blood flow. ${ }^{122}$ Although this model has been particularly valuable for studies of cerebral contusion and consequent edema, it has not been widely used in research focusing on molecular and cellular mechanisms of post-traumatic neuronal cell death. The limited utilization may be explained by the frequent hemorrhages that accompany the injury.

The rat model of moderate head concussion designed by Goldman et al. ${ }^{125}$ utilizes a pendulum falling on the skull midline of animals anesthetized with halothane, approximately $9 \mathrm{~mm}$ anterior to the coronal suture. The optimum applied force and angle of the impact is adjusted using a nomogram interrelating the animal's body weight and desired injury severity. For example, in rats weighing $330-430 \mathrm{~g}$, the selected angle values are ranging from $60^{\circ}$ to $85^{\circ}$ delivers impact energy to the skull varying from 1.62-1.89 J. This model is uncomplicated by skull fractures and contusions, with a histopathology including patchy neuronal degeneration in numerous forebrain locations at $48 \mathrm{~h}$ after trauma. The Goldman method generates early increase in cerebrovascular permeability, decrease in cerebral blood flow, and elevation of intracerebral pressure. ${ }^{125}$ Direct relationship between the severity of injury and the duration of unconsciousness also has been demonstrated. ${ }^{126}$ This model provides a reproducible range of mild to moderate severity of injury, which depends upon pendulum stroke, impact load, and animal body weight. Because this model does not cause skull fractures or subdural-, subarachnoidal-, and intracerebral hemorrhages, and replicates physiological and morphological changes that are comparable to those shown in human TBI, it is recommended for investigating the mechanisms of brain injury and corresponding therapy.

Impact acceleration models (unconstrained). In early impact acceleration models, anesthetized primates were injured by a 1-kg mass impact piston striking the animal's head at a designated location on the skull. ${ }^{127,128}$ Head motion in these models was constrained only by the neck, which allowed close reproduction of the acceleration-deceleration force seen in human head injury. The injury severity was causally related to the velocity, mass, and contact area of the impactor, as well as the type of interface material. These methods were successful in replicating some of major characteristics of human TBI such as short-term loss of consciousness, as well as histopathological, systemic, and cerebral metabolic responses. $^{7}$

The ovine head impact model was developed to study diffuse axonal injury resulting from a graded traumatic insult. ${ }^{129,130}$ Briefly, the anesthetized sheep is placed in the sphinx position with the head positioned on a support to allow free rotational and lateral movement after impact. The impact is generated using a humane stunner that is aimed at the left temporal region of the unrestrained skull. The discharge of a blank cartridge, which is inserted in a chamber behind the proximal end of the bolt, propels a captive bolt from the muzzle of the stunner; the muzzle velocity depends on the predetermined charge. ${ }^{129}$ This model induces widespread axonal injury in the hemispheric white matter, central gray matter, brainstem, and cerebellum, as well as around cerebral contusions. The degree of axonal injury is strongly correlated with systemic and cerebrovascular responses. ${ }^{129}$

One of the shortcomings of the fully unconstrained injury models is the lack of injury reproducibility, particularly in terms of outcome. Thus, aiming to increase the reproducibility of the outcome parameters, other models have been designed with restricted head motion during and after impact. ${ }^{131}$ In these models, the head motion is simply confined to a single plane, thus improving outcome reproducibility without completely restricting head motion. In general, the unconstrained impact acceleration models demonstrate a high degree of variability due to lack of accurate control over biomechanical forces related to impact and head dynamic response. ${ }^{2}$ Hence, the pathophysiological response to injury in these models is inconsistent, albeit useful for morphologic characterization of injury.

Impact acceleration models (constrained). Marmarou's weight drop model ${ }^{132,133}$ is one of the most frequently used constrained rodent models of impact acceleration head injury. The trauma device consists of a column of brass weights falling freely by gravity from a designated height through a Plexiglas tube. After exposing the animal's skull by a midline incision, a stainless steel disc (10 $\mathrm{mm}$ in diameter and $3 \mathrm{~mm}$ in depth) is rigidly fixed with dental cement to the animal's skull centrally between lambda and bregma fissures. The rats are then placed on a 10-cm deep foam bed and the impact generated by dropping the brass weight onto the stainless 
steel disc. This method has been shown to produce graded brain injury in both rats and mice, where the injury severity is directly related to the mass and the height from which the brass weight is released. ${ }^{132,134,135}$ The impact that is induced by a fall of a 450-g weight from a $2-m$ height causes a mortality rate of $44 \%$ with $12.5 \%$ incidence of skull fracture. Because the death is primarily caused by respiratory depression, mechanical ventilation after the impact significantly lowers the mortality rate. ${ }^{132}$ Mathematical calculations show that this mass-height combination generates a brain acceleration of $900 \mathrm{G}$ and a brain compression gradient of 0.28 mm. ${ }^{132}$ Morphological findings include an absence of supratentorial focal brain lesions, with petechial hemorrhages only being present in the brainstem after severe 2-m level injury. Histopathology shows widespread and bilateral damage of the neurons, axons, dendrites, and microvasculature. ${ }^{133,136,137}$ It is noteworthy that this model causes massive diffuse axonal injury, particularly in the corpus callosum, internal capsule, optic tracts, cerebral and cerebellar peduncules, and the long tracts in the brainstem. ${ }^{133}$ The fact that pathomorphological alterations following 2-m injury are more extensive than after $1-\mathrm{m}$ injury, indicates graded neuronal injury in response to impact acceleration. ${ }^{133,138}$ Reduced cerebral blood flow and elevated intracerebral pressure has been shown as a result of loss of cerebral autoregulation during the first $4 \mathrm{~h}$ after the impact. ${ }^{139,140}$ Diffusion-weighted magnetic resonance imaging showed that there is a development of a vasogenic edema immediately after weightdrop impact followed by more widespread and slower edema formation due to a predominantly cellular swelling. ${ }^{141}$ Moreover, the Marmarou model has been shown to induce motor and cognitive deficits, ${ }^{142-144}$ similar to those shown after fluid percussion injury and controlled cortical impact. Cellular and molecular responses to injury generated by this model have been widely analyzed. Alterations in cerebral energy metabolism include reduced ATP, GTP, and nicotinic enzymes (nicotinamide adenine dinucleotide, nicotinamide adenine dinucleotide phosphate) ${ }^{145}$ as well as decreased $\mathrm{N}$-acetylaspartate (its reduction has been accepted a marker of neuronal dysfunction/loss $)^{146}$ starting at $2 \mathrm{~h}$ after injury. Impact acceleration-induced injury also induces a highly significant reduction in free magnesium concentration, cytosolic phosphorylation ratio, and increases the rate of mitochondrial oxidative phosphorylation, with $\mathrm{pH}$ values close to control level. ${ }^{142}$ Additionally, the weight drop TBI model activates proinflammatory mediators/modulators, ${ }^{147-149}$ calpains and caspases, ${ }^{150,151}$ and induces release of cytochrome $c^{150}$ and proapoptotic Bcl-2 family members ${ }^{151}$ from the mitochondria into the cytosol. Consequently, this model induces both apoptotic and necrotic types of neuronal cell death. Although the biomechanics of the impact produced by this model is not fully and strictly controlled, it is inexpensive, easy to perform, and capable of producing graded diffuse axonal injury, hence its popularity.

In the Marmarou model, there is a possibility of a "second hit" induced by the weight after rebounding from the skull of the animal resting on the flexible sponge. Moreover, although the weight is enclosed within a Plexiglas tube, a slight left- and- right movement occurs during its fall; this may potentially lateralize the impact, leading to uneven distribution of the impact energy and increased variability of outcome measures. Because of these shortcomings, we designed a highly controlled and reproducible rat model of diffuse traumatic brain injury. ${ }^{152}$ Our device consists of an airdriven high-velocity impactor that is targeted to contact a steel disc cemented onto the rodent skull. The impactor is of the same diameter as the steel disc, which is $10 \mathrm{~mm}$ in diameter. A molded, gel-filled base (Handstands, Taiwan) supports the animal's head and decelerates after impact. The middle diameter of the gel is $1.7 \mathrm{~cm}$, whereas its compressibility is approximately $64 \mathrm{kPa} / \mathrm{mm}$. To ensure precise and even contact with the steel disc on the animal's skull, the 14-cm-length impactor can be manually lowered onto the steel disc such that the two surfaces meet, whereas a laser beam guide is used to confirm that the two surfaces are parallel and in contact with each other. Having established this point of contact, the impactor is retracted to a $4-\mathrm{cm}$ fixed distance above the steel disc. Impact is then initiated wherein the velocity of the impactor is constant $(3.25 \mathrm{~m} / \mathrm{s})$. The distance the impactor travels after contacting the steel disc determines the injury severity and is under user control. Force of impact is controlled and recorded on a personal computer connected to the device through a PowerLab (Stoelting, Wood Dakem, IL). Compared with Marmarou's weight-drop device, our device enables control of the velocity as well as of the well time, during which the impactor is in contact with the animal's head. ${ }^{152}$ Additionally, the laser-beam incorporated in our device enables precise centralization of the hit, thus prevent uneven delivery of impact energy to the head.

This model of TBI induces brain edema that begins 20 min after injury and peaks at $24 \mathrm{~h}$ after trauma, as shown by wet weight/dry weight ratios and diffusion-weighted magnetic resonance imaging. The permeability of the blood brain barrier is increased up to $4 \mathrm{~h}$ after injury as evaluated using Evans blue dye. Moreover, brain free magnesium concentration and cytosolic phosphorylation potential are significantly reduced, as demonstrated by phosphorus magnetic resonance spectroscopy at $4 \mathrm{~h}$ after injury. Manganese-enhanced magnetic resonance imaging, and intracerebral injection of a fluorescent vital dye (Fluoro-Ruby, Molecular Probes, Inc., Eugene, OR) showed diffuse axonal damage at $24 \mathrm{~h}$ and $7 \mathrm{~d}$ after injury. Morphological evidence of apoptosis and caspase-3 activa- 
tion is also found in the cerebral hemisphere and brainstem at $24 \mathrm{~h}$ after trauma. Taken together, this model successfully replicates major biochemical and neurological changes of diffuse clinical TBI.

\section{Nonimpact head acceleration models}

Movement of the brain within the skull rather than a direct impact to the head has been accepted as the major etiological factor in human closed head injuries. Indeed, it has been demonstrated that rapid rotation of the head is one of the main causes of diffuse brain injury. ${ }^{153}$ Thus, the purpose of nonimpact head acceleration models is to replicate this condition. The rotational acceleration via shearing mechanisms causes diffuse axonal injury accompanied by various pathophysiological and behavioral changes. ${ }^{154}$ The inertial effect, which depends upon the brain mass, determines the extent of tissue deformations. ${ }^{155}$ Hence, acceleration head injury models place special attention on the scaling relationship between the brain mass and acceleration. ${ }^{156}$ Numerous head acceleration models have been developed using nonhuman primates, ${ }^{157,158}$ pigs, ${ }^{159,160}$ rabbits, ${ }^{161}$ and rats ${ }^{162}$; whereas some of these models constrain the motion of the head, others permit free head motion. The recently developed models constrain the head by using various fixation mechanisms ${ }^{159-162}$ because the fully unconstrained head has been shown to increase the variability of the outcome parameters.

The nonhuman primate model uses a pneumatic shock tester to generate a nonimpact, controlled, single rotation, which displaces the head $60^{\circ}$ within $10-20 \mathrm{~ms} .{ }^{157}$ The resulting rotational acceleration is biphasic, with a long acceleration phase followed by a short deceleration phase. The duration of coma, degree of neurological deficit, as well as the intensity of diffuse axonal injury localized in the subcortical white matter, upper brainstem, and cerebellum, are causally related to the mechanical force applied via coronal rotation of the head. ${ }^{163}$ This method reproduces the range of impaired consciousness experienced in brain injured humans and induces widespread axonal damage similar to that found in human brains after severe TBI. ${ }^{158,163}$

Smith et al. ${ }^{160}$ developed a head acceleration model, which induces diffuse brain trauma in miniature swine via head rotational acceleration. Briefly, the head is secured to a pneumatic actuator through a snout clamp. Triggering the pneumatic actuator produces linear motion that is further converted to angular motion through a linkage assembly directly mounted to the device. ${ }^{160,164}$ The center of head rotation is positioned close to the skull base for coronal plane rotation, or at $\mathrm{C}-2$ for axial plane rotation. Activation of the device rapidly rotates the animal's head over the designated angular excursion of $110^{\circ}$ in $20 \mathrm{~ms}$, with the peak acceleration at approximately $6 \mathrm{~ms}$. The ensuing rotational acceleration of the head has a biphasic course, with a predominant deceleration phase. ${ }^{160,165}$ Both coronal and axial rotations induce diffuse axonal injury mainly located in the hemispheric white matter and brainstem. Accumulation of amyloid precursor protein, a marker for diffuse axonal injury, ${ }^{166,167}$ was shown in the white matter of injured animals at 3-10 days after injury. ${ }^{168}$ Moreover, prolonged coma occurs immediately after axial rotation of the head, but not after coronal plate rotation. ${ }^{169}$ The severity of coma is linearly related to the applied kinetic energy, as well as with the extent of axonal injury in the brainstem. ${ }^{160,169}$ Acute reductions in the neuronal marker, $\mathrm{N}$-acetylaspartate, and in intracellular free magnesium levels, persisting for up to 7 days after trauma, ${ }^{165,170}$ are also induced by the Smith model as demonstrated by nuclear magnetic resonance spectroscopy. The changes in intracellular metabolism caused by diffuse axonal damage in the white matter occur in the absence of alterations in $\mathrm{pH}$ and phosphocreatine/inorganic ratio; the concentrations of ATP and lactate also remain close to normal values. ${ }^{170}$

The nonimpact acceleration injury models using nonhuman primates and miniature swine most closely replicate the complex pathobiology of human traumatic brain injury; hence, they offer valuable information on morphological, cellular, and molecular responses to diffuse brain injury. However, their use is difficult for most laboratories due to the cost and size of the animal, as well as the sophisticated technical requirements. ${ }^{11}$ Moreover, the models of acceleration head injury using large experimental animals lack reliable functional outcome tests, which are critical to the preclinical evaluation of neuroprotective treatments.

\section{INDIRECT DYNAMIC BRAIN INJURY}

Although exposure to blast overpressure that is generated during an explosion has been considered to damage primarily organs containing air or containing structures with different densities (ear, lungs, intestine, etc.) ${ }^{171}$ recent clinical and experimental data show that peripheral blast trauma, without direct head injury, causes significant brain damage with consequent cognitive and/or motor system deficits. This brain injury is most likely induced through afferent hyperexcitability, increased synthesis and release of various neurotransmitters and autacoids, and/or kinetic energy transfer of the blast overpressure to the CNS. ${ }^{172,173}$ The induction system routinely used in blast exposure models consists of a cylindrical metal tube that is closed at one end. The anesthetized rats are fixed individually in special holders designed to prevent any movement of their body in response to the blast. The blast over- and under-pressure waves are then generated either by detonation of plastic explosive or compressed air in the closed end of the tube. 
The animals are usually subjected to a blast wave with mean peak overpressure of between 154 and $340 \mathrm{kPa}$ on the nearest surface of the animal's body, whereas the pressure is sustained for varying durations of time. ${ }^{173,174}$ Swelling of neurons, an astroglial response, and myelin debris in the hippocampus has been found following moderate blast injury in animals. ${ }^{173}$ Immunohistochemical findings have demonstrated significant damage to the neuronal cytoskeleton in layers II-IV of the temporal cortex, in the cingulated gyrus and the piriform cortex, the dentate gyrus, and the CA1 region of the hippocampus over 7 days after blast exposure. ${ }^{174}$ Moreover, development of oxidative stress, alterations in antioxidant enzyme defense systems, ${ }^{173}$ increased nitric oxide metabolism, and subsequent cognitive deficits ${ }^{175}$ have been shown. These findings suggest a resemblance between the blast-induced neuronal dysfunction and that found in direct traumatic brain injury. Indeed, it has been reported that the rodent blast exposure model of indirect neurotrauma can induce many features of brain damage observed in victims of an explosion. ${ }^{176,177}$ Hence, the experimental rodent model can be a useful tool to elucidate mechanisms of delayed neuronal dysfunction following blast exposure, and to test potential therapeutics.

\section{COMBINED NEUROTRAUMA MODELS}

Hypoxia, ischemia, hypovolemia, and hypotension frequently accompany traumatic brain injury in animals ${ }^{178-180}$ and humans. ${ }^{181-183}$ The combination of these pathological conditions aggravates functional outcome and increases mortality. ${ }^{181-183}$ Thus, experimental models that combine traumatic brain injury and secondary insults have been designed using rats, ${ }^{178,184,185}$ mice, ${ }^{186}$ cats, ${ }^{28,187}$ and swine. ${ }^{188,189}$ In the TBI-hypoxia models, fluid percussion, ${ }^{178,190,191}$ controlled cortical impact $^{185,192,193}$ or impact-acceleration ${ }^{194,195}$ TBI models are used to inflict neurotrauma, followed by hypoxic conditions $\left(\mathrm{pO}_{2}\right.$ approximately $30-40 \mathrm{~mm} \mathrm{Hg}$ or $\mathrm{FiO}_{2}$ $10-13 \%)$ to induce secondary hypoxia. On the other hand, models that combine mechanical brain injury and hypovolemia and/or hypotension inflict brain injury using one of the above-mentioned experimental TBI models with subsequent hemorrhage, which decreases the mean arterial pressure to $30-50 \mathrm{~mm} \mathrm{Hg} .{ }^{188,189,196}$ Combined neurotrauma models are valuable tools to evaluate the consequences and mechanisms of secondary insults after TBI.

Taken together, no single in vivo model of traumatic brain injury can be recommended as a gold standard for neurotrauma research. Because each animal model offers certain benefits, but also limitations, the choice must be made based on specific research aims and objectives. ${ }^{2,11}$ Utilization of multiple animal models has also been recommended to characterize vital mechanisms involved in the pathobiology of traumatic brain injury. ${ }^{11}$ Moreover, it has been shown that some physiological and biochemical factors, which might be potentially involved in secondary injury following CNS trauma, show species-specific properties ${ }^{197,198}$; hence, using the two models/two species paradigm in in vivo neurotrauma research may increase the consistency and reliability of the results.

\section{CONCLUSION}

Experimental models of TBI are of vital importance in the identification of the complex mechanisms leading to both necrotic and apoptotic neuronal cell death after brain injury. ${ }^{21,53,199}$ A variety of morphological, cellular, molecular, and behavioral changes have been characterized across experimental models and across laboratories, such as changes in ionic homeostasis (calcium, magnesium, sodium, and potassium), generation of free radicals, inflammatory/immune response, release of excitatory amino acids, and alterations in multiple neurotransmitter/ neuromodulator systems. ${ }^{4,200,201}$ These results prompted the development of various therapeutic strategies, such as administration of magnesium, glutamate antagonists, immunomodulators, antioxidants, and antiapoptotic agents, among others. ${ }^{202-205}$ However, pharmacokinetic and pharmacodynamic studies using animal models, as well as studies evaluating central penetration of systemically administered drugs after experimental TBI, are rarely conducted. ${ }^{206}$ Further development of more complex animal models of traumatic brain injury is necessary to reproduce the complete pathobiology of human TBI. These models, which would incorporate hypoxia, ischemia, and other potentially relevant factors of clinical head injury, would be useful in testing combination therapies that prevent various factors of the secondary injury cascade, or single compounds that modulate multiple mechanisms of the cascade. ${ }^{204,207}$ Moreover, there is a need for a reliable and reproducible animal model that reproduces development/age- and gender-dependent responses to traumatic brain injury.

\section{REFERENCES}

1. Reilly PL. Brain injury: the pathophysiology of the first hours. "Talk and Die revisited." J Clin Neurosci 8:398-403, 2001.

2. Lighthall JW, Anderson TE. In: The neurobiology of cenral nervous system trauma (Salzman SK, Faden AI, eds), pp 3-12. New York/Oxford: Oxford University Press, 1994.

3. Adams JH, Doyle D, Ford I, Gennarelli TA, Graham DI, McLellan DR. Diffuse axonal injury in head injury: definition, diagnosis and grading. Histopathology 15:49-59, 1989.

4. McIntosh TK, Smith DH, Meaney DF, Kotapka MJ, Gennarelli TA, Graham DI. Neuropathological sequelae of traumatic brain injury: relationship to neurochemical and biomechanical mechanisms. Lab Invest 74:315-342, 1996.

5. DeKosky ST, Kochanek PM, Clark RS, Ciallella JR, Dixon CE. Secondary injury after head trauma: subacute and long-term mechanisms. Semin Clin Neuropsychiatry 3:176-185, 1998.

6. Denny-Brown D, Russell WR. Experimental cerebral consussion. Brain 64:93-164, 1941. 
7. Ommaya AK, Gennarelli TA. Cerebral concussion and traumatic unconsciousness. Correlation of experimental and clinical observations of blunt head injuries. Brain 97:633-654, 1974.

8. Clark RS, Schiding JK, Kaczorowski SL, Marion DW, Kochanek PM. Neutrophil accumulation after traumatic brain injury in rats: comparison of weight drop and controlled cortical impact models. J Neurotrauma 11:499-506, 1994.

9. Rall JM, Matzilevich DA, Dash PK. Comparative analysis of mRNA levels in the frontal cortex and the hippocampus in the basal state and in response to experimental brain injury. Neuropathol Appl Neurobiol 29:118-131, 2003.

10. Cenci MA, Whishaw IQ, Schallert T. Animal models of neurological deficits: how relevant is the rat? Nat Rev Neurosci 3:574579, 2002

11. Povlishock JT, Hayes RL, Michel ME, McIntosh TK. Workshop on animal models of traumatic brain injury. J Neurotrauma 11: 723-732, 1994.

12. Gennarelli TA. Animate models of human head injury. J Neurotrauma 11:357-368, 1994.

13. Ommaya AK, Goldsmith W, Thibault L. Biomechanics and neuropathology of adult and paediatric head injury. Br J Neurosurg 16:220-242, 2002.

14. Ommaya AK. Head injury mechanisms and the concept of preventive management: a review and critical synthesis. $J$ Neurotrauma 12:527-546, 1995.

15. David S, Aguayo AJ. Axonal regeneration after crush injury of rat central nervous system fibres innervating peripheral nerve grafts. J Neurocytol 14:1-12, 1985.

16. Park HJ, Kim HN, Kim KM. Redistribution of facial nerve motor neurons after recovery from nerve crushing injury in the gerbil. Acta Otolaryngol 115:273-275, 1995.

17. Erb DE, Povlishock JT. Axonal damage in severe traumatic brain injury: an experimental study in cat. Acta Neuropathol (Berl) 76:347-358, 1988.

18. Conti AC, Raghupathi R, Trojanowski JQ, McIntosh TK. Experimental brain injury induces regionally distinct apoptosis during the acute and delayed post-traumatic period. J Neurosci 18:5663$5672,1998$.

19. Albensi BC, Knoblach SM, Chew BG, O'Reilly MP, Faden AI, Pekar JJ. Diffusion and high resolution MRI of traumatic brain injury in rats: time course and correlation with histology. Exp Neurol 162:61-72, 2000.

20. McIntosh TK, Yu T, Gennarelli TA. Alterations in regional brain catecholamine concentrations after experimental brain injury in the rat. J Neurochem 63:1426-1433, 1994.

21. Faden AI, Demediuk P, Panter SS, Vink R. The role of excitatory amino acids and NMDA receptors in traumatic brain injury. Science 244:798-800, 1989.

22. Faden AI, Knoblach SM, Cernak I, Fan L, Vink R, Araldi GL, et al. Novel diketopiperazine enhances motor and cognitive recovery after traumatic brain injury in rats and shows neuroprotection in vitro and in vivo. J Cereb Blood Flow Metab 23:342-354, 2003.

23. Dixon CE, Lighthall JW, Anderson TE. Physiologic, histopathologic, and cineradiographic characterization of a new fluid-percussion model of experimental brain injury in the rat. $J$ Neurotrauma 5:91-104, 1988.

24. Perri BR, Smith DH, Murai H, Sinson G, Saatman KE, Raghupathi $R$, et al. Metabolic quantification of lesion volume following experimental traumatic brain injury in the rat. $J$ Neurotrauma 14:15-22, 1997.

25. Carbonell WS, Maris DO, McCall T, Grady MS. Adaptation of the fluid percussion injury model to the mouse. $J$ Neurotrauma 15:217-229, 1998.

26. Carbonell WS, Grady MS. Regional and temporal characterization of neuronal, glial, and axonal response after traumatic brain injury in the mouse. Acta Neuropathol (Berl) 98:396-406, 1999.

27. Sullivan HG, Martinez J, Becker DP, Miller JD, Griffith R, Wist AO. Fluid-percussion model of mechanical brain injury in the cat. J Neurosurg 45:521-534, 1976.

28. Zauner A, Clausen T, Alves OL, Rice A, Levasseur J, Young HF, et al. Cerebral metabolism after fluid-percussion injury and hypoxia in a feline model. J Neurosurg 97:643-649, 2002.
29. Pfenninger EG, Reith A, Breitig D, Grunert A, Ahnefeld FW. Early changes of intracranial pressure, perfusion pressure, and blood flow after acute head injury. Part 1: an experimental study of the underlying pathophysiology. J Neurosurg 70:774-779, 1989.

30. Gibson JB, Maxwell RA, Schweitzer JB, Fabian TC, Proctor KG. Resuscitation from severe hemorrhagic shock after traumatic brain injury using saline, shed blood, or a blood substitute. Shock 17:234-244, 2002.

31. Hartl R, Medary M, Ruge M, Arfors KE, Ghajar J. Blood-brain barrier breakdown occurs early after traumatic brain injury and is not related to white blood cell adherence. Acta Neurochir Suppl (Wien) 70:240-242, 1997.

32. Millen JE, Glauser FL, Fairman RP. A comparison of physiological responses to percussive brain trauma in dogs and sheep. J Neurosurg 62:587-591, 1985.

33. McIntosh TK, Noble L, Andrews B, Faden AI. Traumatic brain injury in the rat: characterization of a midline fluid-percussion model. Cent Nerv Syst Trauma 4:119-134, 1987.

34. Schmidt RH, Grady MS. Regional patterns of blood-brain barrier breakdown following central and lateral fluid percussion injury in rodents. J Neurotrauma 10:415-430, 1993.

35. McIntosh TK, Vink R, Noble L, Yamakami I, Fernyak S, Soares $\mathrm{H}$, et al. Traumatic brain injury in the rat: characterization of a lateral fluid- percussion model. Neuroscience 28:233-244, 1989.

36. Marmarou A, Shima K. Comparative studies of edema produced by fluid percussion injury with lateral and central modes of injury in cats. Adv Neurol 52:233-236, 1990.

37. Raghupathi R, McIntosh TK, Smith DH. Cellular responses to experimental brain injury. Brain Pathol 5:437-442, 1995.

38. Thibault LE, Meaney DF, Anderson BJ, Marmarou A. Biomechanical aspects of a fluid percussion model of brain injury. J Neurotrauma 9:311-322, 1992.

39. Vink R, Mullins PG, Temple MD, Bao W, Faden AI. Small shifts in craniotomy position in the lateral fluid percussion injury model are associated with differential lesion development. I Neurotrauma 18:839-847, 2001.

40. Floyd CL, Golden KM, Black RT, Hamm RJ, Lyeth BG. Craniectomy position affects morris water maze performance and hippocampal cell loss after parasagittal fluid percussion. J Neurotrauma 19:303-316, 2002.

41. Thompson HJ, Lifshitz J, Marklund N, Grady MS, Graham DI, Hovda DA, et al. Lateral fluid percussion brain injury: a 15-year review and evaluation. $J$ Neurotrauma 22:42-75, 2005.

42. Iwamoto Y, Yamaki T, Murakami N, Umeda M, Tanaka C, Higuchi T, et al. Investigation of morphological change of lateral and midline fluid percussion injury in rats, using magnetic resonance imaging. Neurosurgery 40:163-167, 1997.

43. Dixon CE, Lyeth BG, Povlishock JT, Findling RL, Hamm RJ, Marmarou A, et al. A fluid percussion model of experimental brain injury in the rat. J Neurosurg 67:110-119, 1987.

44. Atkinson JL, Anderson RE, Murray MJ. The early critical phase of severe head injury: importance of apnea and dysfunctional respiration. J Trauma 45:941-945, 1998.

45. Qian L, Ohno K, Maehara T, Tominaga B, Hirakawa K, Kuroiwa $\mathrm{T}$, et al. Changes in $\mathrm{CBF}$, morphology and related parameters by fluid percussion injury. Acta Neurochir (Wien) 138:90-98, 1996.

46. Muir JK, Boerschel M, Ellis EF. Continuous monitoring of posttraumatic cerebral blood flow using laser-Doppler flowmetry. J Neurotrauma 9:355-362, 1992.

47. Tanno H, Nockels RP, Pitts LH, Noble LJ. Breakdown of the blood-brain barrier after fluid percussion brain injury in the rat. Part 2: effect of hypoxia on permeability to plasma proteins. J Neurotrauma 9:335-347, 1992.

48. Povlishock JT, Kontos HA. Continuing axonal and vascular change following experimental brain trauma. Cent Nerv Syst Trauma 2:285-298, 1985.

49. Dietrich WD, Alonso O, Halley M. Early microvascular and neuronal consequences of traumatic brain injury: a light and electron microscopic study in rats. J Neurotrauma 11:289-301, 1994.

50. Pettus EH, Povlishock JT. Characterization of a distinct set of intra-axonal ultrastructural changes associated with traumatically 
induced alteration in axolemmal permeability. Brain Res 722:111, 1996.

51. Wang YJ, Shimura T, Kobayashi S, Teramoto A, Nakazawa S. A lateral fluid percussion model for the experimental severe brain injury and a morphological study in the rats. Nippon Ika Daigaku Zasshi 64:172-175, 1997.

52. Graham DI, Raghupathi R, Saatman KE, Meaney D, McIntosh TK. Tissue tears in the white matter after lateral fluid percussion brain injury in the rat: relevance to human brain injury. Acta Neuropathol (Berl) 99:117-124, 2000.

53. Yakovlev AG, Knoblach SM, Fan L, Fox GB, Goodnight R, Faden AI. Activation of CPP32-like caspases contributes to neuronal apoptosis and neurological dysfunction after traumatic brain injury. J Neurosci 17:7415-7424, 1997.

54. Kita T, Tanaka T, Tanaka N, Kinoshita Y. The role of tumor necrosis factor- $\alpha$ in diffuse axonal injury following fluid-percussive brain injury in rats. Int J Legal Med 113:221-228, 2000.

55. Okiyama K, Smith DH, Thomas MJ, McIntosh TK. Evaluation of a novel calcium channel blocker, (S)-emopamil, on regional cerebral edema and neurobehavioral function after experimental brain injury. J Neurosurg 77:607-615, 1992.

56. Osteen CL, Moore AH, Prins ML, Hovda DA. Age-dependency of 45 calcium accumulation following lateral fluid percussion: acute and delayed patterns. J Neurotrauma 18:141-162, 2001.

57. McIntosh TK, Soares H, Thomas M, Cloherty K. Development of regional cerebral oedema after lateral fluid-percussion brain injury in the rat. Acta Neurochir Suppl (Wien) 51:263-264, 1990.

58. Soares HD, Thomas M, Cloherty K, McIntosh TK. Development of prolonged focal cerebral edema and regional cation changes following experimental brain injury in the rat. $J$ Neurochem 58 : 1845-1852, 1992.

59. Sun FY, Faden AI. Neuroprotective effects of 619C89, a usedependent sodium channel blocker, in rat traumatic brain injury. Brain Res 673:133-140, 1995.

60. Katayama Y, Becker DP, Tamura T, Hovda DA. Massive increases in extracellular potassium and the indiscriminate release of glutamate following concussive brain injury. J Neurosurg 73: 889-900, 1990.

61. D'Ambrosio R, Maris DO, Grady MS, Winn HR, Janigro D. Impaired $\mathrm{K}(+)$ homeostasis and altered electrophysiological properties of post-traumatic hippocampal glia. J Neurosci 19: 8152-8162, 1999.

62. McIntosh TK, Faden AI, Bendall MR, Vink R. Traumatic brain injury in the rat: alterations in brain lactate and $\mathrm{pH}$ as characterized by $1 \mathrm{H}$ and $31 \mathrm{P}$ nuclear magnetic resonance. $J$ Neurochem 49:1530-1540, 1987.

63. Vink R, McIntosh TK, Demediuk P, Weiner MW, Faden AI. Decline in intracellular free $\mathrm{Mg} 2+$ is associated with irreversible tissue injury after brain trauma. J Biol Chem 263:757-761, 1988.

64. McIntosh TK, Faden AI, Yamakami I, Vink R. Magnesium deficiency exacerbates and pretreatment improves outcome following traumatic brain injury in rats: $31 \mathrm{P}$ magnetic resonance spectroscopy and behavioral studies. J Neurotrauma 5:17-31, 1988.

65. Saija A, Robinson SE, Lyeth BG, Dixon CE, Yamamoto T, Clifton GL, et al. The effects of scopolamine and traumatic brain injury on central cholinergic neurons. J Neurotrauma 5:161-170, 1988.

66. Vink R, Golding EM, Headrick JP. Bioenergetic analysis of oxidative metabolism following traumatic brain injury in rats. J Neurotrauma 11:265-274, 1994.

67. Baker AJ, Phan N, Moulton RJ, Fehlings MG, Yucel Y, Zhao M, et al. Attenuation of the electrophysiological function of the corpus callosum after fluid percussion injury in the rat. $J$ Neurotrauma 19:587-599, 2002.

68. Hayes RL, Katayama Y, Young HF, Dunbar JG. Coma associated with flaccidity produced by fluid-percussion concussion in the cat. I: Is it due to depression of activity within the brainstem reticular formation? Brain Inj 2:31-49, 1988.

69. Hamm RJ, Pike BR, O'Dell DM, Lyeth BG, Jenkins LW. The rotarod test: an evaluation of its effectiveness in assessing motor deficits following traumatic brain injury. J Neurotrauma 11:187196, 1994.

70. Smith DH, Okiyama K, Thomas MJ, Claussen B, McIntosh TK.
Evaluation of memory dysfunction following experimental brain injury using the Morris water maze. J Neurotrauma 8:259-269, 1991.

71. Hamm RJ, Lyeth BG, Jenkins LW, O’Dell DM, Pike BR. Selective cognitive impairment following traumatic brain injury in rats. Behav Brain Res 59:169-173, 1993.

72. Hogg S, Moser PC, Sanger DJ. Mild traumatic lesion of the right parietal cortex of the rat: selective behavioural deficits in the absence of neurological impairment. Behav Brain Res 93:143$155,1998$.

73. Lighthall JW. Controlled cortical impact: a new experimental brain injury model. J Neurotrauma 5:1-15, 1988.

74. Dixon CE, Clifton GL, Lighthall JW, Yaghmai AA, Hayes RL. A controlled cortical impact model of traumatic brain injury in the rat. J Neurosci Methods 39:253-262, 1991.

75. Goodman JC, Cherian L, Bryan RM Jr, Robertson CS. Lateral cortical impact injury in rats: pathologic effects of varying cortical compression and impact velocity. J Neurotrauma 11:587597, 1994.

76. Smith DH, Soares HD, Pierce JS, Perlman KG, Saatman KE, Meaney DF, et al. A model of parasagittal controlled cortical impact in the mouse: cognitive and histopathologic effects. $\mathrm{J} \mathrm{Neu}$ rotrauma 12:169-178, 1995.

77. Cherian L, Robertson CS, Contant CF Jr, Bryan RM Jr. Lateral cortical impact injury in rats: cerebrovascular effects of varying depth of cortical deformation and impact velocity. J Neurotrauma 11:573-585, 1994.

78. Lighthall JW, Goshgarian HG, Pinderski CR. Characterization of axonal injury produced by controlled cortical impact. J Neurotrauma 7:65-76, 1990.

79. Palmer AM, Marion DW, Botscheller ML, Swedlow PE, Styren SD, DeKosky ST. Traumatic brain injury-induced excitotoxicity assessed in a controlled cortical impact model. J Neurochem 61:2015-2024, 1993.

80. Fox GB, Fan L, Levasseur RA, Faden AI. Sustained sensory/ motor and cognitive deficits with neuronal apoptosis following controlled cortical impact brain injury in the mouse. $J$ Neurotrauma 15:599-614, 1998.

81. Scheff SW, Baldwin SA, Brown RW, Kraemer PJ. Morris water maze deficits in rats following traumatic brain injury: lateral controlled cortical impact. J Neurotrauma 14:615-627, 1997.

82. Meaney DF, Ross DT, Winkelstein BA, Brasko J, Goldstein D, Bilston LB, et al. Modification of the cortical impact model to produce axonal injury in the rat cerebral cortex. $J$ Neurotrauma 11:599-612, 1994.

83. Matthews MA, Carey ME, Soblosky JS, Davidson JF, Tabor SL. Focal brain injury and its effects on cerebral mantle, neurons, and fiber tracks. Brain Res 794:1-18, 1998.

84. Newcomb JK, Zhao X, Pike BR, Hayes RL. Temporal profile of apoptotic-like changes in neurons and astrocytes following controlled cortical impact injury in the rat. Exp Neurol 158:76-88, 1999.

85. Dunn-Meynell AA, Levin BE. Histological markers of neuronal, axonal and astrocytic changes after lateral rigid impact traumatic brain injury. Brain Res 761:25-41, 1997.

86. Baskaya MK, Rao AM, Dogan A, Donaldson D, Dempsey RJ. The biphasic opening of the blood-brain barrier in the cortex and hippocampus after traumatic brain injury in rats. Neurosci Lett 226:33-36, 1997.

87. Bryan RM Jr, Cherian L, Robertson C. Regional cerebral blood flow after controlled cortical impact injury in rats. Anesth Analg 80:687-695, 1995.

88. Prasad MR, Ramaiah C, McIntosh TK, Dempsey RJ, Hipkens S, Yurek D. Regional levels of lactate and norepinephrine after experimental brain injury. J Neurochem 63:1086-1094, 1994.

89. Colicos MA, Dash PK. Apoptotic morphology of dentate gyrus granule cells following experimental cortical impact injury in rats: possible role in spatial memory deficits. Brain Res 739:120 131, 1996.

90. Smith DH, Nakamura M, McIntosh TK, Wang J, Rodriguez A, Chen $\mathrm{XH}$, et al. Brain trauma induces massive hippocampal neuron death linked to a surge in $\beta$-amyloid levels in mice overex- 
pressing mutant amyloid precursor protein. Am J Pathol 153: 1005-1010, 1998.

91. Kaya SS, Mahmood A, Li Y, Yavuz E, Goksel M, Chopp M. Apoptosis and expression of $\mathrm{p} 53$ response proteins and cyclin D1 after cortical impact in rat brain. Brain Res 818:23-33, 1999.

92. Beer R, Franz G, Schopf M, Reindl M, Zelger B, Schmutzhard E, et al. Expression of Fas and Fas ligand after experimental traumatic brain injury in the rat. J Cereb Blood Flow Metab 20:669677, 2000.

93. Matzilevich DA, Rall JM, Moore AN, Grill RJ, Dash PK. Highdensity microarray analysis of hippocampal gene expression following experimental brain injury. J Neurosci Res 67:646-663, 2002.

94. Long Y, Zou L, Liu H, Lu H, Yuan X, Robertson CS, et al. Altered expression of randomly selected genes in mouse hippocampus after traumatic brain injury. J Neurosci Res 71:710720, 2003.

95. Kawamata T, Katayama Y, Maeda T, Mori T, Aoyama N, Kikuchi T, et al. Antioxidant, OPC-14117, attenuates edema formation and behavioral deficits following cortical contusion in rats. Acta Neurochir Suppl (Wien) 70:191-193, 1997.

96. Verweij BH, Muizelaar JP, Vinas FC, Peterson PL, Xiong Y, Lee CP. Mitochondrial dysfunction after experimental and human brain injury and its possible reversal with a selective N-type calcium channel antagonist (SNX-111). Neurol Res 19:334-339, 1997.

97. Faden AI, Fox GB, Fan L, Araldi GL, Qiao L, Wang S, et al. Novel TRH analog improves motor and cognitive recovery after traumatic brain injury in rodents. Am J Physiol (Lond) 277: R1196-R1204, 1999.

98. Kroppenstedt SN, Stroop R, Kern M, Thomale UW, Schneider $\mathrm{GH}$, Unterberg AW. Lubeluzole following traumatic brain injury in the rat. $J$ Neurotrauma 16:629-637, 1999.

99. Dempsey RJ, Baskaya MK, Dogan A. Attenuation of brain edema, blood-brain barrier breakdown, and injury volume by ifenprodil, a polyamine-site N-methyl-D-aspartate receptor antagonist, after experimental traumatic brain injury in rats. Neurosurgery 47:399-404, 2000.

100. Sullivan PG, Thompson M, Scheff SW. Continuous infusion of cyclosporin A postinjury significantly ameliorates cortical damage following traumatic brain injury. Exp Neurol 161:631-637, 2000.

101. Di X, Zhang T, Mullins P, Faden AI. Novel, potent, and selective group II mGluR agonist LY379268 ameliorates cognitive and motor deficits induced by control cortical impact injury in mouse. J Neurotrauma 17:960, 2000.

102. Faden AI, Fox GB, Di X, Knoblach SM, Cernak I, Mullins P, et al. Neuroprotective and nootropic actions of a novel cyclized dipeptide after controlled cortical impact injury in mice. J Cereb Blood Flow Metab 23:355-363, 2003.

103. Shreiber DI, Bain AC, Ross DT, Smith DH, Gennarelli TA, McIntosh TK, et al. Experimental investigation of cerebral contusion: histopathological and immunohistochemical evaluation of dynamic cortical deformation. J Neuropathol Exp Neurol 58:153164, 1999.

104. Shreiber DI, Smith DH, Meaney DF. Immediate in vivo response of the cortex and the blood-brain barrier following dynamic cortical deformation in the rat. Neurosci Lett 259:5-8, 1999.

105. Fitch MT, Doller C, Combs CK, Landreth GE, Silver J. Cellular and molecular mechanisms of glial scarring and progressive cavitation: in vivo and in vitro analysis of inflammation-induced secondary injury after CNS trauma. J Neurosci 19:8182-8198, 1999.

106. Mathew P, Bullock R, Graham DI, Maxwell WL, Teasdale GM, McCulloch J. A new experimental model of contusion in the rat. Histopathological analysis and temporal patterns of cerebral blood flow disturbances. J Neurosurg 85:860-870, 1996.

107. Sun D, Tani M, Newman TA, Krivacic K, Phillips M, Chernosky A, et al. Role of chemokines, neuronal projections, and the bloodbrain barrier in the enhancement of cerebral EAE following focal brain damage. J Neuropathol Exp Neurol 59:1031-1043, 2000.

108. Ghirnikar RS, Lee YL, He TR, Eng LF. Chemokine expression in rat stab wound brain injury. J Neurosci Res 46:727-733, 1996.
109. Burger R, Bendszus M, Vince GH, Roosen K, Marmarou A. A new reproducible model of an epidural mass lesion in rodents. Part I: characterization by neurophysiological monitoring, magnetic resonance imaging, and histopathological analysis. J Neurosurg 97:1410-1418, 2002.

110. Allen IV, Scott R, Tanner JA. Experimental high-velocity missile head injury. Injury 14:183-193, 1982.

111. Carey ME, Sarna GS, Farrell JB. Brain edema following an experimental missile wound to the brain. J Neurotrauma 7:13-20, 1990.

112. Finnie JW. Pathology of experimental traumatic craniocerebral missile injury. J Comp Pathol 108:93-101, 1993.

113. Finnie JW. Brain damage caused by a captive bolt pistol. J Comp Pathol 109:253-258, 1993.

114. Carey ME. Experimental missile wounding of the brain. Neurosurg Clin N Am 6:629-642, 1995.

115. Carey ME, Sarna GS, Farrell JB. Brain edema after an experimental missile wound. Adv Neurol 52:301-305, 1990.

116. Carey ME, Sarna GS, Farrell JB, Happel LT. Experimental missile wound to the brain. J Neurosurg 71:754-764, 1989.

117. Beckman DL, Bean JW. Pulmonary pressure-volume changes attending head injury. J Appl Physiol 29:631-636, 1970.

118. Bakay L, Lee JC, Lee GC, Peng JR. Experimental cerebral concussion. Part 1: An electron microscopic study. J Neurosurg 47:525-531, 1977.

119. Nilsson B, Ponten U, Voigt G. Experimental head injury in the rat. Part 1: mechanics, pathophysiology, and morphology in an impact acceleration trauma model. J Neurosurg 47:241-251, 1977.

120. Lighthall JW, Dixon CE, Anderson TE. Experimental models of brain injury. J Neurotrauma 6:83-97, 1989.

121. Tornheim PA, McLaurin RL. Acute changes in regional brain water content following experimental closed head injury. J Neurosurg 55:407-413, 1981.

122. Tornheim PA, McDermott F, Shiguma M. Effect of experimental blunt head injury on acute regional cerebral blood flow and edema. Adv Neurol 52:377-384, 1990.

123. Tornheim PA, Liwnicz BH, Hirsch CS, Brown DL, McLaurin RL. Acute responses to blunt head trauma. Experimental model and gross pathology. J Neurosurg 59:431-438, 1983.

124. Wagner KR, Tornheim PA, Eichhold MK. Acute changes in regional cerebral metabolite values following experimental blunt head trauma. J Neurosurg 63:88-96, 1985.

125. Goldman H, Hodgson V, Morehead M, Hazlett J, Murphy S. Cerebrovascular changes in a rat model of moderate closed-head injury. J Neurotrauma 8:129-144, 1991.

126. Morehead M, Bartus RT, Dean RL, Miotke JA, Murphy S, Sall J, et al. Histopathologic consequences of moderate concussion in an animal model: correlations with duration of unconsciousness. J Neurotrauma 11:657-667, 1994.

127. Gurdjian ES, Lissner HR, Webster JE, Latimer FR, Haddad BF. Studies on experimental concussion. Neurology 4:674-681, 1954.

128. Ommaya AK, Grubb RL Jr, Naumann RA. Coup and contre-coup injury: observations on the mechanics of visible brain injuries in the rhesus monkey. J Neurosurg 35:503-516, 1971.

129. Lewis SB, Finnie JW, Blumbergs PC, Scott G, Manavis J, Brown $\mathrm{C}$, et al. A head impact model of early axonal injury in the sheep. J Neurotrauma 13:505-514, 1996.

130. Van Den Heuvel C, Lewis S, Wong M, Manavis J, Finnie J, Blumbergs $\mathrm{P}$, et al. Diffuse neuronal perikaryon amyloid precursor protein immunoreactivity in a focal head impact model. Acta Neurochir Suppl 71:209-211, 1998.

131. Gosch HH, Gooding E, Schneider RC. The lexan calvarium for the study of cerebral responses to acute trauma. J Trauma 10: 370-376, 1970.

132. Marmarou A, Foda MA, van den Brink W, Campbell J, Kita H, Demetriadou K. A new model of diffuse brain injury in rats. Part I: Pathophysiology and biomechanics. J Neurosurg 80:291-300, 1994.

133. Foda MA, Marmarou A. A new model of diffuse brain injury in rats. Part II: Morphological characterization. J Neurosurg 80: 301-313, 1994. 
134. Piper IR, Thomson D, Miller JD. Monitoring weight drop velocity and foam stiffness as an aid to quality control of a rodent model of impact acceleration neurotrauma. J Neurosci Methods 69:171-174, 1996.

135. De Mulder G, Van Rossem K, Van Reempts J, Borgers M, Verlooy J. Validation of a closed head injury model for use in long-term studies. Acta Neurochir Suppl 76:409-413, 2000.

136. Folkerts MM, Berman RF, Muizelaar JP, Rafols JA. Disruption of MAP-2 immunostaining in rat hippocampus after traumatic brain injury. J Neurotrauma 15:349-363, 1998.

137. Kallakuri S, Cavanaugh JM, Ozaktay AC, Takebayashi T. The effect of varying impact energy on diffuse axonal injury in the rat brain: a preliminary study. Exp Brain Res 148:419-424, 2003.

138. Povlishock JT, Marmarou A, McIntosh T, Trojanowski JQ, Moroi $\mathrm{J}$ Impact acceleration injury in the rat: evidence for focal axolemmal change and related neurofilament sidearm alteration. $J \mathrm{Neu}$ ropathol Exp Neurol 56:347-359, 1997.

139. Engelborghs K, Verlooy J, Van Deuren B, Van Reempts J, Borgers M. Intracranial pressure in a modified experimental model of closed head injury. Acta Neurochir Suppl (Wien) 70:123-125, 1997.

140. Prat R, Markiv V, Dujovny M, Misra M. Failure of cerebral autoregulation in an experimental diffuse brain injury model. Acta Neurochir Suppl (Wien) 71:123-126, 1998.

141. Barzo P, Marmarou A, Fatouros P, Hayasaki K, Corwin F. Biphasic pathophysiological response of vasogenic and cellular edema in traumatic brain swelling. Acta Neurochir Suppl (Wien) 70:119-122, 1997.

142. Heath DL, Vink R. Impact acceleration-induced severe diffuse axonal injury in rats: characterization of phosphate metabolism and neurologic outcome. J Neurotrauma 12:1027-1034, 1995.

143. Schmidt RH, Scholten KJ, Maughan PH. Cognitive impairment and synaptosomal choline uptake in rats following impact acceleration injury. J Neurotrauma 17:1129-1139, 2000.

144. Vink R, O'Connor CA, Nimmo AJ, Heath DL. Magnesium attenuates persistent functional deficits following diffuse traumatic brain injury in rats. Neurosci Lett 336:41-44, 2003.

145. Vagnozzi R, Marmarou A, Tavazzi B, Signoretti S, Di Pierro D, del Bolgia F, et al. Changes of cerebral energy metabolism and lipid peroxidation in rats leading to mitochondrial dysfunction after diffuse brain injury. J Neurotrauma 16:903-913, 1999.

146. Signoretti S, Marmarou A, Tavazzi B, Lazzarino G, Beaumont A, Vagnozzi R. N-acetylaspartate reduction as a measure of injury severity and mitochondrial dysfunction following diffuse traumatic brain injury. J Neurotrauma 18:977-991, 2001.

147. Cernak I, O'Connor C, Vink R. Activation of cyclo-oxygenase-2 contributes to motor and cognitive dysfunction following diffuse traumatic brain injury in rats. Clin Exp Pharmacol Physiol 28: 922-925, 2001.

148. Rhodes JK, Andrews PJ, Holmes MC, Seckl JR. Expression of interleukin- 6 messenger RNA in a rat model of diffuse axonal injury. Neurosci Lett 335:1-4, 2002.

149. Cernak I, O'Connor C, Vink R. Inhibition of cyclooxygenase 2 by nimesulide improves cognitive outcome more than motor outcome following diffuse traumatic brain injury in rats. Exp Brain Res 147:193-199, 2002.

150. Buki A, Okonkwo DO, Wang KK, Povlishock JT. Cytochrome c release and caspase activation in traumatic axonal injury. $\mathrm{J} \mathrm{Neu}$ rosci 20:2825-2834, 2000.

151. Cernak I, Chapman SM, Hamlin GP, Vink R. Temporal characterisation of pro- and anti-apoptotic mechanisms following diffuse traumatic brain injury in rats. J Clin Neurosci 9:565-572, 2002.

152. Cernak I, Vink R, Zapple DN, Cruz MI, Ahmed F, Chang T, et al. The pathobiology of moderate diffuse traumatic brain injury as identified using a new experimental model of injury in rats. Neurobiol Dis 17:29-43, 2004.

153. Holbourn AH. Mechanics of head injuries. Lancet 2:438-441, 1943.

154. Meythaler JM, Peduzzi JD, Eleftheriou E, Novack TA. Current concepts: diffuse axonal injury-associated traumatic brain injury. Arch Phys Med Rehabil 82:1461-1471, 2001.
155. Margulies SS, Thibault LE. An analytical model of traumatic diffuse brain injury. J Biomech Eng 111:241-249, 1989.

156. Meaney DF, Margulies SS, Smith DH. Diffuse axonal injury. J Neurosurg 95:1108-1110, 2001.

157. Gennarelli TA, Adams JH, Graham DI. Acceleration induced head injury in the monkey. I. The model, its mechanical and physiological correlates. Acta Neuropathol Suppl (Berl) 7:23-25, 1981.

158. Gennarelli TA. Head injury in man and experimental animals: clinical aspects. Acta Neurochir Suppl (Wien) 32:1-13, 1983.

159. Ross DT, Meaney DF, Sabol MK, Smith DH, Gennarelli TA. Distribution of forebrain diffuse axonal injury following inertial closed head injury in miniature swine. Exp Neurol 126:291-299, 1994.

160. Smith DH, Chen XH, Xu BN, McIntosh TK, Gennarelli TA, Meaney DF. Characterization of diffuse axonal pathology and selective hippocampal damage following inertial brain trauma in the pig. J Neuropathol Exp Neurol 56:822-834, 1997.

161. Gutierrez E, Huang Y, Haglid K, Bao F, Hansson HA, Hamberger A, et al. A new model for diffuse brain injury by rotational acceleration: I model, gross appearance, and astrocytosis. $\mathrm{J} \mathrm{Neu}$ rotrauma 18:247-257, 2001.

162. Xiao-Sheng H, Sheng-Yu Y, Xiang Z, Zhou F, Jian-ning Z. Diffuse axonal injury due to lateral head rotation in a rat model. J Neurosurg 93:626-633, 2000.

163. Gennarelli TA, Thibault LE, Adams JH, Graham DI, Thompson CJ, Marcincin RP. Diffuse axonal injury and traumatic coma in the primate. Ann Neurol 12:564-574, 1982.

164. Meaney DF, Smith DH, Shreiber DI, Bain AC, Miller RT, Ross DT, et al. Biomechanical analysis of experimental diffuse axonal injury. J Neurotrauma 12:689-694, 1995.

165. Cecil KM, Lenkinski RE, Meaney DF, McIntosh TK, Smith DH. High-field proton magnetic resonance spectroscopy of a swine model for axonal injury. J Neurochem 70:2038-2044, 1998.

166. Gentleman SM, Nash MJ, Sweeting CJ, Graham DI, Roberts GW. $\beta$-Amyloid precursor protein ( $\beta \mathrm{APP})$ as a marker for axonal injury after head injury. Neurosci Lett 160:139-144, 1993.

167. Sherriff FE, Bridges LR, Sivaloganathan S. Early detection of axonal injury after human head trauma using immunocytochemistry for $\beta$-amyloid precursor protein. Acta Neuropathol (Berl) 87:55-62, 1994.

168. Smith D, Chen X, Nonaka M, Trojanowski J, Lee V, Saatman K, et al. Accumulation of amyloid $\beta$ and $\tau$ and the formation of neurofilament inclusions following diffuse brain injury in the pig. J Neuropathol Exp Neurol 58:982-992, 1999.

169. Smith DH, Nonaka M, Miller R, Leoni M, Chen XH, Alsop D, et al. Immediate coma following inertial brain injury dependent on axonal damage in the brainstem. J Neurosurg 93:315-322, 2000.

170. Smith DH, Cecil KM, Meaney DF, Chen XH, McIntosh TK, Gennarelli TA, et al. Magnetic resonance spectroscopy of diffuse brain trauma in the pig. J Neurotrauma 15:665-674, 1998.

171. Clemedson CJ. Blast injury. Physiol Rev 36:336-354, 1956.

172. Cernak I, Savic J, Malicevic Z, Zunic G, Radosevic P, Ivanovic I, et al. Involvement of the central nervous system in the general response to pulmonary blast injury. J Trauma 40:S100-S104, 1996.

173. Cernak I, Wang Z, Jiang J, Bian X, Savic J. Ultrastructural and functional characteristics of blast injury-induced neurotrauma. J Trauma 50:695-706, 2001.

174. Saljo A, Bao F, Haglid KG, Hansson HA. Blast exposure causes redistribution of phosphorylated neurofilament subunits in neurons of the adult rat brain. J Neurotrauma 17:719-726, 2000.

175. Cernak I, Wang Z, Jiang J, Bian X, Savic J. Cognitive deficits following blast injury-induced neurotrauma: possible involvement of nitric oxide. Brain Inj 15:593-612, 2001.

176. Cernak I, Savic J, Ignjatovic D, Jevtic M. Blast injury from explosive munitions. J Trauma 47:96-103; discussion 103-104, 1999.

177. Cernak I, Savic VJ, Kotur J, Prokic V, Veljovic M, Grbovic D. Characterization of plasma magnesium concentration and oxidative stress following graded traumatic brain injury in humans. $J$ Neurotrauma 17:53-68, 2000. 
178. Ishige N, Pitts LH, Berry I, Carlson SG, Nishimura MC, Moseley ME, et al. The effect of hypoxia on traumatic head injury in rats: alterations in neurologic function, brain edema, and cerebral blood flow. J Cereb Blood Flow Metab 7:759-767, 1987.

179. Ishige N, Pitts LH, Berry I, Nishimura MC, James TL. The effects of hypovolemic hypotension on high-energy phosphate metabolism of traumatized brain in rats. J Neurosurg 68:129-136, 1988.

180. Chen M, Clark RS, Kochanek PM, Chen J, Schiding JK, Stetler RA, et al. 72-kDa heat shock protein and mRNA expression after controlled cortical impact injury with hypoxemia in rats. $\mathrm{J} \mathrm{Neu}$ rotrauma 15:171-181, 1998.

181. Graham DI, Ford I, Adams JH, Doyle D, Teasdale GM, Lawrence $\mathrm{AE}$, et al. Ischaemic brain damage is still common in fatal nonmissile head injury. J Neurol Neurosurg Psychiatry 52:346-350, 1989.

182. Chesnut RM. Secondary brain insults after head injury: clinical perspectives. New Horiz 3:366-375, 1995.

183. Manley G, Knudson MM, Morabito D, Damron S, Erickson V, Pitts L. Hypotension, hypoxia, and head injury: frequency, duration, and consequences. Arch Surg 136:1118-1123, 2001.

184. Bramlett HM, Green EJ, Dietrich WD. Exacerbation of cortical and hippocampal CA1 damage due to posttraumatic hypoxia following moderate fluid-percussion brain injury in rats. $J$ Neurosurg 91:653-659, 1999.

185. Beaumont A, Marmarou A, Fatouros P, Corwin F. Secondary insults worsen blood brain barrier dysfunction assessed by MRI in cerebral contusion. Acta Neurochir Suppl 81:217-219, 2002.

186. Ditelberg JS, Sheldon RA, Epstein CJ, Ferriero DM. Brain injury after perinatal hypoxia-ischemia is exacerbated in copper/zinc superoxide dismutase transgenic mice. Pediatr Res 39:204-208, 1996.

187. Kimelberg HK, Cragoe EJ Jr, Nelson LR, Popp AJ, Szarowski D, Rose JW, et al. Improved recovery from a traumatic-hypoxic brain injury in cats by intracisternal injection of an anion transport inhibitor. Cent Nerv Syst Trauma 4:3-14, 1987.

188. Zink BJ, Stern SA, Wang X, Chudnofsky CC. Effects of ethanol in an experimental model of combined traumatic brain injury and hemorrhagic shock. Acad Emerg Med 5:9-17, 1998.

189. Stern SA, Zink BJ, Mertz M, Wang X, Dronen SC. Effect of initially limited resuscitation in a combined model of fluid-percussion brain injury and severe uncontrolled hemorrhagic shock. J Neurosurg 93:305-314, 2000.

190. Bramlett HM, Dietrich WD, Green EJ. Secondary hypoxia following moderate fluid percussion brain injury in rats exacerbates sensorimotor and cognitive deficits. J Neurotrauma 16:10351047, 1999.

191. Matsushita Y, Shima K, Nawashiro H, Wada K. Real-time monitoring of glutamate following fluid percussion brain injury with hypoxia in the rat. $J$ Neurotrauma 17:143-153, 2000.
192. Clark RS, Kochanek PM, Dixon CE, Chen M, Marion DW, Heineman S, et al. Early neuropathologic effects of mild or moderate hypoxemia after controlled cortical impact injury in rats. J Neurotrauma 14:179-189, 1997.

193. Cai Z, Schools GP, Kimelberg HK. Metabotropic glutamate receptors in acutely isolated hippocampal astrocytes: developmental changes of mGluR5 mRNA and functional expression. Glia 29:70-80, 2000.

194. Nawashiro H, Shima K, Chigasaki H. Selective vulnerability of hippocampal CA3 neurons to hypoxia after mild concussion in the rat. Neurol Res 17:455-460, 1995.

195. Katoh H, Sima K, Nawashiro H, Wada K, Chigasaki H. The effect of MK-801 on extracellular neuroactive amino acids in hippocampus after closed head injury followed by hypoxia in rats. Brain Res 758:153-162, 1997.

196. Yamamoto M, Marmarou CR, Stiefel MF, Beaumont A, Marmarou A. Neuroprotective effect of hypothermia on neuronal injury in diffuse traumatic brain injury coupled with hypoxia and hypotension. J Neurotrauma 16:487-500, 1999.

197. Johansson CB, Lothian C, Molin M, Okano H, Lendahl U. Nestin enhancer requirements for expression in normal and injured adult CNS. J Neurosci Res 69:784-794, 2002.

198. Yoburn BC, Lutfy K, Candido J. Species differences in $\mu$ - and

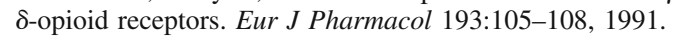

199. Rink A, Fung KM, Trojanowski JQ, Lee VM, Neugebauer E, McIntosh TK. Evidence of apoptotic cell death after experimental traumatic brain injury in the rat. Am J Pathol 147:1575-1583, 1995.

200. Faden AI. Experimental neurobiology of central nervous system trauma. Crit Rev Neurobiol 7:175-186, 1993.

201. Yakovlev AG, Faden AI. Molecular biology of CNS injury. J Neurotrauma 12:767-777, 1995.

202. Faden AI. Pharmacologic treatment of acute traumatic brain injury. JAMA 276:569-570, 1996.

203. McIntosh TK, Juhler M, Wieloch T. Novel pharmacologic strategies in the treatment of experimental traumatic brain injury: 1998. J Neurotrauma 15:731-769, 1998.

204. Faden AI. Neuroprotection and traumatic brain injury: theoretical option or realistic proposition. Curr Opin Neurol 15:707-712, 2002.

205. Vink R, Nimmo AJ. Novel therapies in development for the treatment of traumatic brain injury. Expert Opin Investig Drugs 11:1375-1386, 2002.

206. Faden AI. Neuroprotection and traumatic brain injury: the search continues. Arch Neurol 58:1553-1555, 2001.

207. Faden AI. Comparison of single and combination drug treatment strategies in experimental brain trauma. J Neurotrauma 10:91100, 1993. 